\title{
Comparative Study on the Operation of Australian Jury System and Chinese Courts
}

\author{
Huijing Yu \\ China University of Political Science and Law, Beijing, 100089, China
}

Keywords: Comparative study, Australian jury system, Chinese courts

\begin{abstract}
The jury system, one of the oldest judicial systems in the world, is a democratic form of citizen's direct participation in judicial activities and a safeguard mechanism for the rights of the citizens. It is formed in Britain and with the expansion of colonial domination, the jury system developed rapidly in Australia. The paper compares the jury system of Australia and Chinese courts and points out the differences of the selection conditions, selection procedures, relative rights, value orientations and safeguard measures to provide some reference for the relative researchers.
\end{abstract}

\section{Introduction}

The jury system refers to the judicial democracy system that the state judicial organ absorbs the non-legal profession to participate in the court trial, and exercises the judicial power together with the professional judge. From the view of the world, the jury system mainly has two forms: the Anglo-American jury system and continental law system. The assessor system of our current jury system called for jury trial, the jury must determine facts and applicable law and. The jury system in China and the United States can be said to represent two different modes of civil participation in justice, namely jury system and trial system. To develop and perfect the system of people's assessors in China, this article intends to make a comparative analysis with the most complete Australian jury system in the world. After a long period of historical evolution, the jury system in Australia has formed a universal jury concept and common consciousness, which is based on the recognition of the jury system in the history. The jury system in China lacks the evolution process of the same kind of system, which leads to the lack of the idea and common consciousness of the jury. In addition, Australia's jury system after a long historical evolution, the formation of a series of related supporting system and the jury system, jury system perfects the system such as the adversarial trial system, jury system, which is formed in the long-time accumulation based on the experience, they are guaranteed effectively the implementation of the jury system. Of course, compared to the trial case by the judge alone, the people's jury participating in the trial of the case will inevitably increase the cost of justice. But don't forget, that takes the cost to compensate for the losses caused by the truth than trudged after more meaningful. We should be aware that not all cases will be introduced into the people's jury trial, only to meet the people's Jury Trial Provisions of the scope of cases enabled the people's jury, this shows that the people's jury trial the number of cases will not be great. Moreover, this kind of judicial cost cannot be reduced as much as possible through system design. This is just an idea, and needs further exploration and discovery in practice. Chinese people's jury system lacks historical foundation, not a process of birth, growth, maturity of the system, but also the lack of a common system should have a universal consciousness of the people, just passively imitated his country mode. Therefore, the people jury system has not been in a proper position in our country for a long time, and then cannot play its proper role.

\section{Comparison of Australian Jury System with Chinese Courts}

Different Selection Conditions. According to the relevant provisions of our country, citizens should serve as the people's assessors should meet the conditions of supporting the constitution of the People's Republic of China, twenty-three years of age, good conduct, justice, decency and good 
health. Have a college degree or above. At the same time to meet some provisions, for example, members of the Standing Committee of the people's Congress of the people's court, the people's Procurator ate and the public security organs, state security organs, judicial and administrative organs of the staff and other personnel occupation lawyer, not as people's assessors; given a criminal punishment for a crime, was expelled from office staff shall not serve as the jury. The people's jury selection methods are recommended by their units or domicile of the organizations at the grass-roots level to the grassroots people's court, or by my application, by the grassroots people's court in conjunction with the people's conquest of the judicial administrative organs for review, and by the president of the grassroots people's Court of the people's jury candidates shall be submitted to the Standing Committee at the corresponding level the people's Congress appointed. According to the relevant provisions of the law of Australia, shall comply with the conditions must be an Australian citizen, must reach a basic age, living in the trial area, state regulations, the scope is generally between eighteen to twenty-five years old. The prohibition is once have been convicted of a felony; deaf and blind; do not have the ability to read or write; everything, refused to take the oath promise or announcement said is the fact that people of Australia; infidelity; physical or mental defects, and the defects in their chosen as the jury has been proved to hinder the exercise of normal function; people who don't understand English or the jury. In Australia, the list of jurors is generated from the voter list, registration license list, can also choose to update from other time extensive list, as long as according to the list, can from the society comprehensive and fair produce jurors. The chosen person should be screened by a judge or lawyer, and in conformity with the above conditions, he can truly become a member of the jury.

Different Selection Procedures. The procedure in the jury, in accordance with the relevant provisions of our people's jury is composed of the basic people's Congress elections, and the jury is composed of Australian voters by the court according to the selection rules of random decision. To represent social justness and safeguard the jury, the jury system in Australia and a series of corresponding procedures for withdrawal, and adapt to the peremptory challenge resulting Australian jury is our people's jury has complicated procedures, there is no generation of our people's jury is convenient efficient. From another point of view, the complexity of the procedure for Australian jurors also ensures the rationality of jury formation and guarantees the impartiality of jury decisions to a maximum extent. The jury system has far-reaching historical roots in Australia, an Australian citizen as a jury trial is a constitutional right, the jury system and the Australian political system fit, strong legal system to support system with associated and jury. The jury system in Australia works well and has vitality. In contrast, our people's jury system still has some defects that cannot be ignored in the trial activities less for the jury, jury into foil, jury form, the overall quality of the jury is low, cannot play a big role in the judicial practice, operation effect and expected the people's jury system far away. The jury of Australia has no fixed term and is optional. In our country, there is no uniform and rigid specific amount for the number of jurors. The criminal procedure law of China only stipulates the basic people's courts. The intermediate people's court of first instance can be composed of judges and people's assessors totaling three collegiate benches; the higher people's court of the Supreme People's Court of first instance criminal cases by judges and people's assessors three to seven form a collegial panel in civil cases of first instance trial, the judge may with the jury members of a collegial panel. From the legal provisions of our country, the number of people's assessors in the full court is small and uncertain, and in judicial practice, the number of cases involving jurors is very little. The term of office of the people's assessors is generally five years, and may be reelected.

Different Relative Rights. The rights and obligations of the jury in China, a jury and a judge, and the judge must implement the same challenge system, jurisdiction system and regulations, collegial incentives and other aspects, which is based on our country is leading to mixed mode of trial, the jury during the trial and judges to participate the trial of cases, the so-called assessor system. The people's jury and judge the basic rights are the same, namely reading files and participate in the investigation of the case; in the trial of the case; in the case of collegiate; participate in relevant legal knowledge and business knowledge training rights trial. In terms of obligations, the people's assessors should be law-abiding, learn and publicize the law, attend the jury on time, and keep the state secrets and trial 
secrets. In Australia, there is a large jury and a small jury. The grand jury is mainly used in the criminal procedure, its nature is equivalent to the procurator ate, often is composed of the twenty-three seats of the ordinary citizens, it is the main function of before the court formally opened, summoned the case with the witnesses and evidence, to decide whether the case against major cases of controversial. If the collegial panel considers that a case should be organized for trial by the people's jury, the full court shall report it to the presiding judge of the business court where it has been approved and approved by the head of the court. This kind of people's jury trial initiation mode with a strong power of authority directly ignores the choice of procedure by litigants. Whether the people's jury is involved in the trial or not is closely related to the interests of the parties. In any case, they cannot skip their opinions and try to organize the trial. If the parties choose the people's jury, he will bear the jury trial for all the benefits of his, but if he had no choice, that is passive under such results, this is a serious violation of the litigation rights of the parties, but also to the substantive results are a big hit the mark. Secondly, if the negative results are taken, the party will cause serious distrust and conflict to the jury, which is extremely harmful to the survival and development of the people's jury system. Once again, it is the right of the defendant to accept the trial of the people's jury, only to consult the opinions of the public prosecution organs, to completely ignore the defendant, and obviously to lose justice. The grand jury automatically dissolved after the decision was made and the prosecutor took over the case. The small jury, also known as the trial jury, participated in the federal court or the state court of criminal, civil and other cases of first instance. Its right in criminal cases is to examine the evidence, listen to the debate, and decide whether the defendant is guilty or not; in civil cases, it is the decision whether the defendant constitutes an infringement. If the jury finds innocent or does not constitute infringement, the defendant or defendant is released in court; however, if the jury finds guilty or constitutes infringement, the judge shall then make a legal decision to punish him. The jury of Australia usually finds only the facts, and the application of the law is the work of professional judges.

Different Value Orientations. China's people's courts organizational law stipulates that the ninth article: the people's court trial of the first instance, there are judges composed of collegial panel, or by judges and people's assessors composed of collegial panel. This provision clearly jury trial system, which makes the selection through legal procedures of people's assessors to enjoy parallel jurisdiction, and the people's jury is representative of the interests of the masses, the masses of the people is also involved in the management of the country to exercise the rights. Political rights; at the same time also makes the people to exercise their right of judicial supervision, effective supervision of the judicial system, ensure judicial fairness and justice. The Australian jury plays an important role in Australia's judicial system, which effectively defends and protects freedom. The jury system enables judicial jurisdiction to be shared with Australian citizens, through which other powers are restricted, thereby guaranteeing civil liberties. A famous French political thinker Tocqueville once said, the implementation of the jury system can put people themselves, or at least part of the citizens mentioned in the status of judges, this is the jury system, the leading social power into people's hands or a part of citizens. That is, the jury can share the jurisdiction with the judge. At the same time, as a citizen's right to participate in the trial, the jury's participation has effectively restricted the abuse of judicial power. In addition, jury system not only has the function of judicature, but also has the function of making law. Sometimes the jury's verdict may be out of line with the law, because they are moved by some of the words or actions of the party, and then make such a ruling. In practice, the judge does not deny the power of the ruling; instead, he will seek a legal basis for the ruling. Australia's law is more concerned with the appropriateness of the law to amend the law than to deny the jury. The jury acted as an amendment to the law.

Different Safeguard Measures. Two kinds of safeguard measures of the jury system in the judicial practice in Australia, to ensure smooth and stable operation of the jury system, has formed a series of mature regulations strictly control each link of the operation of the jury system. For example, in the process of jury selection, the principle of equality between men and women, the principle of racial equality, and the avoidance and absence of because avoidance guarantee the social representation and impartiality of the jury. This is even more pronounced in the jury trial procedure, 
the jury rule, the principle of the judge, the direction of the jury, and the veto principle of the jury are extremely important safeguards. In addition to these provisions concerning the operation of the jury system, there are corresponding legal systems, such as the trial system, the defense system and the precedent system, which help the jury system operate and make it gradually perfect. The jury system in Australia has achieved remarkable results, mainly due to these mature and careful systems and measures. In addition, the Anglo-American jury system is related to the "adversary system" in the proceedings of Anglo American law. Jury system must require both parties to produce their evidentiary materials in court and to inquire and debate each other to find out the facts. Jurors are always on the sidelines and can only listen to the opinions and arguments of both parties passively. He does not need to organize lawsuits, nor does he need to collect evidence himself. Therefore, the jury system in Australia is also decided by the form of litigation of the "adversary system" in australia. The people's jury system of our country in this respect compared to inferior by comparison, no provisions to regulate the system operation, just stay on the surface, the effect is very weak. Under the common law rule, a jury is not required for a misdemeanor sentence of imprisonment of not less than 6 months. In civil cases, the trial of more than $\$ 20$ in the common law, including personal injury and breach of contract, would certainly apply to jury trials, and equitable cases would not be subject to jury trial. In our country, all kinds of cases can be applied to the people's assessor system, but in practice, there are more jurors in criminal cases, but fewer civil cases and administrative cases.

\section{Conclusions}

The jury system of Australia has formed a mature system in the development and reforms of several hundred years. The jury system not only reflects the perfection of the Australian judicial system, but also reflects the democratization degree of the citizens. We should take the actual social and cultural environment of our country as the basis and draw on the advanced experiences of the jury system in Australia to further perfect the Chinese courts.

\section{References}

[1] Zheng Chengliang, Li Wenjie. People Jury Practice: Considerations and Reflections on Chinese Legal Based on the Run of Jury in Three Court Shanghai [J]. Law Science Magazine, 2016(11): 77-88.

[2] Liang Junyu. The Perfect Method and Institutional Response of the Chinese People's Jury System Reform: Update the Intellectual Source by Resolving Problems about the Jury of Administrative Litigation [J]. Journal of Southwest University of Political Science \& Law, 2015, 17(6): 65-74.

[3] Pan Jingui, Cai Dailin. On the Development of Mechanism for Substantial Jury Reform [J]. Journal of Guizhou Minzu University (Philosophy and Social Sciences), 2016(3): 172-180.

[4] Wu Xuyang. The Behavior Experiment Comparative Study of Jury Mode [J]. Academic Monthly, 2017(1): 104-116. 